\title{
Walled Buildings, Sustainability, and Housing Prices: An Artificial Neural Network Approach
}

\author{
Rita Yi Man $\mathrm{Li}^{1, *(1)}$, Ka Yi Cheng ${ }^{1}$ and Muhammad Shoaib ${ }^{2}$ \\ 1 Sustainable Real Estate Research Center/HKSYU Real Estate and Economics Research Lab, Department of \\ Economics and Finance, Hong Kong Shue Yan University, Hong Kong, China; srerc@hksyu.edu \\ 2 Department of Construction Engineering and Management, School of Civil and Environmental Engineering, \\ National University of Science and Technology, Islamabad 44000, Pakistan; shoaib.cem05@nit.nust.edu.pk \\ * Correspondence: ymli@hksyu.edu; Tel.: +852-2570-7110
}

Received: 1 March 2018; Accepted: 17 April 2018; Published: 23 April 2018

\begin{abstract}
Various researchers have explored the adverse effects of walled buildings on human health. However, few of them have examined the relationship between walled buildings and private housing estates in Hong Kong. This study endeavors to fill the research gap by exploring the connections among walled-building effects, housing features, macroeconomic factors, and housing prices in private housing estates. Specifically, it reveals the relationship between walled buildings and housing prices. Eight privately owned housing estates are selected with a total of 11,365 observations. Results are analyzed to study the factors that affect the housing price. Firstly, unit root tests are carried out to evaluate if the time series variables follow the unit root process. Secondly, the relationship between walled buildings and housing price is examined by conducting an artificial neural network. We assumed that the housing price reduces due to walled-building effects, given that previous literature showed that heat island effect, and blockage of natural light and views, are common in walled-building districts. Moreover, we assume that housing price can also be affected by macroeconomic factors and housing features, and these effects vary among private housing estates. We also study these impacts by using the two models. Recommendations and possible solutions are suggested at the end of the research paper.
\end{abstract}

Keywords: heat island effect; walled buildings; sustainability

\section{Introduction}

Housing scarcity has always been the most chronic issue in Hong Kong and has been discussed widely for decades [1]. The densely populated skyscrapers offer an ingenious solution to the ever-increasing population density brought by approximately 150 new immigrants per day. Gross Floor Areas (GFAs) offer developers bonuses and exemptions for green feature provisions; these are powerful motivations to add extra floors and building masses. However, this results in their greed to maximize all the permissible GFAs by expanding the building structures vertically. This expansion in building mass accelerates the pace of redevelopment amongst low-rise buildings such as railway stations and warehouses [2], and skyscrapers are built in playgrounds or small gardens between the towers of skyscrapers. All these factors give rise to a distinctive new landmark in Hong Kong, namely walled buildings.

Clusters of skyscrapers stand close together, resembling a 'wall' that blocks natural ventilation [3] and sunlight. The emergence of this special feature in Hong Kong in recent years has given rise to a new term, 'walled buildings'. Green Sense defined walled buildings in Hong Kong, according to six standards and features. In the first case, sufficient space between building blocks has not been provided by developers: for instance, the distance between building blocks is below $15 \mathrm{~m}$. Second, 
building blocks are built close together in the form of a long row. Third, the average height of each block, including a podium, is above 35 floors. Fourth, they are in the dominant area of the district, such as the waterfront, town center, or airflow path. Fifth, the widest side of the whole housing estate is facing prevailing wind conditions. Sixth, buildings with lower average height are located near walled buildings. If three or more standards are satisfied or matched, the development is classified as a walled building [4]. Whilst walled buildings provide solutions to the ever-rising demand for housing units in Hong Kong, the microclimate is affected by the urban morphology parameters [5], and residents living nearby may suffer from problems such as poor health or ventilation due to walled buildings (see Section 2 for details).

Although the disadvantages brought by walled buildings are omnipresent in Hong Kong, no prior research has studied the relationship between walled buildings and housing price. The objective of this paper, therefore, is to examine this relationship; it will fill the gap by analyzing the salient features of walled buildings and housing prices of eight residential estates in Hong Kong. Unit root tests are conducted to test for the existence of unit root, and artificial neural networks are used to test the relationship between housing prices and the negative impact bought by walled buildings. Conclusions and recommendations are made based on the test results.

\section{Literature Review}

\subsection{Impact of Walled Buildings on the Hong Kong Concrete Jungle}

\subsubsection{Increased Temperature and Energy Use}

Whilst vegetation in rural areas absorbs most of the energy from the sun through photosynthesis, thus lowering the temperature, urban assembled structures trap this warmth [6]. Because artificial surfaces have greater heat storage capacity than natural ones, differences in advective and convective flows increase the anthropogenic heat release in urban areas and escalate the buildings' energy usage $[7,8]$. This is particularly significant in tropical urban communities such as Hong Kong: the increase in temperature leads to an increase in usage of air conditioning systems that push the indoor heat energy outdoors, thus making the outdoor space hotter [6]. The Hong Kong Energy Statistics Annual Reports show the electricity consumption of major users, including domestic, commercial, and industrial, from 1970 to 2016: the electricity consumption pattern has changed greatly since the 1970s. The upward trend in electricity consumption over the past ten years [9] is partly caused by the concrete jungle, leading to a more urgent need for energy management to reduce the environmental impact [10].

\subsubsection{Walled Buildings Reduce Ventilation}

Towers of walled buildings act as a screen that prevents the wind from blowing in and out of the city. One previous study showed that the average wind speed with the existence of walled buildings was four times lower than without this problem [6], as the wind path is blocked. Ventilation depletion adds to the warmth of a city, leading to increased needs for artificial aerating and cooling, or moderating by successful ventilation [8].

Low buildings should be built near or on the waterfront, while tall buildings should be constructed in the inner part of the city; this aims to reduce the heat island effect, reduce the air flow path obstruction, and avoid the 'walled' effects. Locating taller buildings close to others deprives inner-city residents of views of the sea, making it a privilege for the workers and residents within tall buildings. The Hong Kong Institute of Planners [2] pinpointed that walled buildings obstruct natural ventilation and sunlight; additionally, they add to the poor air quality and block the wind path [11]. 


\subsubsection{Reducing Natural Light and Increasing Mental Health Problems}

Previous research shows that there are numerous advantages of natural light [12]: it allows people to feel less exhausted and work more efficiently. Natural sunlight reduces stress, and students and teachers have better attendance and academic performance. On the other hand, walled buildings block the natural light, the streets and housing units become dimmer, and insufficient light levels produce negative health effects for citizens. For example, people who live near walled buildings suffer from a lack of vitamin $\mathrm{D}[4,13]$. Residents are more stressed and depressed; the probability of suffering from cancer also increases [13]. In addition, people are living without adequate mood support [14], and may have a higher body mass index [14].

\subsubsection{Walled Buildings Worsen the Heat Island Effect}

The urban heat island (UHI) refers to the phenomenon whereby urban areas tend to have higher surface or atmospheric temperatures than their surroundings [15]. This is usually associated with an exacerbation of air pollution and heat waves, leading to an increase in morbidity and mortality, and it inevitably poses a threat to human health $[7,8,16,17]$. Many urban places have experienced UHI: for example, it has become increasingly serious in Beijing. The newly built areas exhibited the highest level-3 surface intensity and frequency of UHIs [15]. Moreover, the expanded utilization of impenetrable land surfaces and dense development are exacerbating the UHI problem [8]. Green Sense [4] proposes that the heat island effect is increasing due to walled buildings. Buildings with a large heat capacity absorb and store heat energy in the daytime, so the temperature in urban areas rises slowly; afterwards, buildings release the heat energy at night. However, the process of releasing heat energy has been slowed and hindered due to walled buildings, as air temperature declines at a decreasing rate.

Consider the case of the suburbs in Adelaide, for example, where most of the buildings are low-rise, wind is not blocked by the buildings that much even if they are in a cluster, and ventilation is not seriously affected. Nevertheless, when the buildings are so tall that the "solid walls" block wind flow and natural sunlight completely, that inevitably worsens the heat island effect.

In summary, due to the adverse implications associated with walled buildings, home buyers may vote with their feet, which will be reflected in lower housing prices.

\subsection{Economic Factors That Affect Property Prices}

Income growth and the unemployment rate are major factors which affect housing price trends. Significant income growth, together with a relatively low unemployment rate, tend to increase the demand for housing [18]. Moreover, a study expressed that economic factors such as unemployment rate are important elements in determining the residential price index [19]. Thus, unemployment rate and income growth should be considered when carrying out research relating to housing price. From a different perspective, however, another piece of research suggested that poor households usually have a steeper bid-rent curve than the rich ones, and skilled labor moves away from the employment center where the Central Business District is located $[20,21]$. Thus, there is no consensus on the relationship between employment and housing prices.

It is undeniable that the interest rate is an essential factor when buying a house, as it is strongly related to the cost of investment. It is necessary to indicate that the housing price often slumps while the real interest rate is climbing: these two factors move in contradictory directions [18]. For instance, real property prices have been contradictive with the real mortgage rate, especially in 1998.

Based on the literature review, our major aim is to study the impact of walled buildings on housing prices. One major problem caused by walled buildings is the heat island effect, which is associated with problems of health, ventilation, and increased energy usage. We then propose that because of these negative impacts, housing demand is lowered and housing estates nearby are associated with a 
lower housing price. We have developed two hypotheses to test whether walled buildings in Hong Kong affect the housing price:

H1: Blocking natural light and views, caused by walled buildings nearby, have negative impacts on the housing price.

$\mathrm{H} 2$ : The heat island effect lowers the housing price (temperature higher than Waglan Island, an island in Hong Kong without any buildings, acts as a proxy for heat island effect).

\section{Research Method}

In this research paper, we firstly identified the large-scale housing estates which fulfilled the criteria of walled buildings (refer to the Introduction), and subsequently located large-scale housing estates nearby which are affected by these walled buildings. The reason for selecting only these large-scale housing estates is that more frequent transactions can be found only amongst such estates. Indeed, some single-block buildings may not have had transactions within ten years. The rationale for choosing these estates is discussed in Section 3.3. We adopted the unit root test to identify any nonstationary variables, and then utilized the artificial neural network to study the weights of the various variables which may affect housing price.

\subsection{Unit Root Test}

First, it is important to identify any nonstationary variables in the regression. If nonstationary variables are included in the model, biased standard errors may occur and the relationship between different variables may be questionable [22]. The presence of unit root characteristics in time series data affects model choice and selection; failure to perform pretesting increases the likelihood of spurious inference. Thus, time series literature often stresses the importance of unit roots tests [23]. To test the unit root hypothesis, we follow the ADF test according to Zhang et al. [24]:

$$
\Delta \mathrm{y}_{\mathrm{t}}=\varphi \mathrm{y}_{\mathrm{t}-1}+\mathrm{X}_{\mathrm{t}}^{\mathrm{i}} \gamma+\sum_{\mathrm{i}-1}^{\mathrm{k}} \Delta \mathrm{y}_{\mathrm{t}-1}+\mu_{\mathrm{t}}
$$

where $y$ denotes the variable which needs to be examined for the presence of a unit root in the period $t$; $\Delta$ represents the first difference operator, such that $\Delta \mathrm{y}_{\mathrm{t}-1}=\mathrm{y}_{\mathrm{t}-1}-\mathrm{y}_{\mathrm{t}-2} ; \mathrm{X}_{\mathrm{t}}^{\mathrm{i}} \gamma$ is an exogenous variable with a constant trend or a constant; and $\mu_{\mathrm{t}}$ represents the error term with the meaning 0 and variance of $\sigma^{2}$. To test the null hypothesis of the presence of a unit root in $y_{t}, \varphi=0$ is tested. The null hypothesis for the presence of unit root is rejected if $\varphi$ is significantly less than zero. Thus, all the dependent and independent variables are tested by the unit root test, to ensure that there is no unit root in the dataset.

\subsection{Artificial Neural Network}

An artificial neural network (ANN) is a machine learning algorithm that mimics the human brain's nervous system. It learns by correlating the input variables with the corresponding output variables to determine the relationship between the variables, and can handle very complex and nonlinear systems $[25,26]$. As compared with other data analysis approaches, it is a useful tool for extracting patterns directly from big data, with a few a priori assumptions [27]. It is also well known for its flexibility. Although the relationship among elements is not vivid, it behaves as a black box that analyzes the dataset and produces results [28]. Data related to the dependent variable are included in the model to train the ANN, which learns the pattern in data with three layers. Specifically, an input layer, a hidden layer, and an output layer are three major elements in the model. This is a powerful tool for data analysis: it has been applied in many disciplines, such as neurophysiology, robotics, and social science, for purposes of pattern recognition, classification, forecasting, etc. [29]. It is believed that the ANN method is more efficient than the linear regression method.

The model is applied in different areas. For example, Carleo and Troyer introduced a variational representation of quantum states via ANNs [30], while Chokshi et al. presented an ANN-based phase 
distribution prediction model for tailored hot stamping, using the data generated from an extensive instrumented nanoindentation-based phase quantification method and thermo-mechanical physical simulation experiments [31].

In this research, the steps of the ANN are as follows [32]. Firstly, the system determines the number of hidden nodes. Secondly, the maximum number of iterations and learning rate are set. Weights and thresholds are assigned to small random numbers. Thresholds are weighted according to the inputs. Thirdly, input vector and output are shown at the input nodes and output nodes, respectively. Fourthly, all inputs are sent to hidden nodes, which are also the input layers in the model, in order to detect and analyze all possible relationships among variables. Weights are assigned to inputs according to the degree of importance: larger-weight values are assigned to important inputs, and vice versa. Input is calculated at the hidden nodes as:

$$
a_{j}^{h}=\sum_{i=1}^{n} W_{i j}^{h} x_{i}
$$

The output value is calculated for the hidden nodes as:

$$
x_{j}^{h}=f\left(a_{j}^{h}\right)=\frac{1}{1+e^{-a_{j}^{h}}}
$$

The results are analyzed further in hidden layers and are sent to output layers through neurons. They are examined one more time in output layers. Inputs are calculated and sent to the output nodes as:

$$
a_{k}=\sum_{j=1}^{L} W_{j k} x_{j}^{h}
$$

As a result, the output that is produced has been investigated by three layers consecutively and respectively; therefore, the relationship among variables will be clearer. The output is calculated as:

$$
\widehat{\mathrm{Y}}_{\mathrm{k}}=\mathrm{f}\left(\mathrm{a}_{\mathrm{k}}\right)=\frac{1}{1+\mathrm{e}^{-\mathrm{a}_{\mathrm{k}}}}
$$

where $\mathrm{k}=1$,

$\widehat{Y_{\mathrm{k}}}=\widehat{\mathrm{Y}}$,

$\mathrm{L}=$ number of hidden nodes.

Fifth, at the end of the process, the error terms are calculated for output layers and hidden nodes to improve the accuracy of the output. The error term is calculated for output nodes as:

$$
\delta_{\mathrm{k}}=(\mathrm{Y}-\widehat{\mathrm{Y}}) \mathrm{f}^{\prime}\left(\mathrm{a}_{\mathrm{k}}\right)
$$

The error term is calculated for hidden nodes as:

$$
\delta_{\mathrm{j}}^{\mathrm{h}}=\mathrm{f}^{\prime}\left(\mathrm{a}_{\mathrm{j}}^{\mathrm{h}}\right) \sum_{\mathrm{k}} \delta_{\mathrm{k}} \mathrm{W}_{\mathrm{jk}}
$$

The weights of the hidden layers and output layers are thus renovated. The weights of the output layer are updated as:

$$
\mathrm{W}_{\mathrm{jk}}(\mathrm{t}+1)=\mathrm{W}_{\mathrm{jk}}(\mathrm{t})+\mathrm{n} \delta_{\mathrm{k}} \mathrm{x}_{\mathrm{j}}^{\mathrm{h}}
$$

The weights of the hidden layer are also updated as:

$$
\mathrm{W}_{\mathrm{ij}}(\mathrm{t}+1)=\mathrm{W}_{\mathrm{ij}}(\mathrm{t})+\mathrm{n} \delta_{\mathrm{j}}^{\mathrm{h}} \mathrm{x}_{\mathrm{i}}
$$




\subsection{Description of Data and Variables}

\subsubsection{Grand Waterfront}

The Grand Waterfront is a modern housing estate; its developers are the Henderson Land Development Company Limited and The Hong Kong and China Gas Company Limited. The date of occupation permit was 7 November 2006. It is classified as a walled building in Hong Kong because it fulfills five out of six Green Sense standards of walled buildings [33]: the housing estate is built along the waterfront, with insufficient space between blocks of buildings, and hence a long row of towers is formed. The average height of each block is 62 floors, which is far higher than the standards, and Wyler Gardens is a nearby housing estate with lower average height. It fulfills five out of the six standards of walled buildings.

\subsubsection{Wyler Gardens}

Wyler Gardens is a private housing estate situated near the Grand Waterfront. The estate consists of three parts, namely Wei Chien Court, Hang Chien Court and Chong Chien Court; the occupational permit dates were 18 May 1979, 8 May 1979, and 17 January 1978, respectively. The average height of each block is 14 floors. The housing estate is included in this study because it is in front of the Grand Waterfront estate; therefore, the effects of Grand Waterfront on its price can be examined.

\subsubsection{Harbour Green}

Harbour Green is another modern private housing estate, whose developers are Sun Hung Kai Properties and the MTR Corporation. The date of occupation permit was 28 September 2006. It is a typical example of a walled building in Hong Kong as it fulfills all the six requirements. The housing estate has been built without sufficient spacing among blocks of buildings, and consequently a long row has been formed. The average height of each block is above 50 floors, which is far more than the specified 35 floors: this strongly affects the air path in Tai Kok Tsui [33]. The widest side of the whole housing estate also faces the prevailing wind. The Cosmopolitan Estate, which is a nearby private housing estate, is built with lower average height. Therefore, Harbour Green is a typical example of a walled building in Hong Kong.

\subsubsection{Cosmopolitan Estate}

The Cosmopolitan Estate is a private housing estate consisting of 15 blocks with different dates of occupation permit, from 15 May 1974 to 12 February 1976. The average height of each block is 13 floors, which is far lower than Harbour Green. It is included due to the short distance from Harbour Green. The housing price may thus be affected by the negative effects of walled buildings.

\subsubsection{Tolo Place}

Tolo Place is a private housing estate, whose developer is Henderson Real Estate Agency Limited. The date of occupation permit was 10 October 1996. It fulfills three out of the six standards of walled buildings: a long row of the building is formed, which blocks the air path of Ma on Shan. Bayshore Towers, which is a private housing estate with lower average height, is built near Tolo Place.

\subsubsection{Bayshore Towers}

Bayshore Towers is a private housing estate; its developer is Cheung King Real Estate Agency Limited, and the date of occupation permit was 24 December 1994. The average height of each block is 24 to 28 floors; it is the nearest housing estate to Tolo Place. It acts as a variable in the model, as it may be affected by walled buildings. 


\subsubsection{Festival City}

Festival City's developer is United City Investments Limited; it was constructed in three phases, their dates of occupation permit being 3 February 2010, 15 November 2010, and 28 December 2011. It is classified as a walled building as it fulfills four out of the six standards. There is insufficient space between building blocks, and a long row has been formed. The average height of each phase is 43,44 , and 49 floors, respectively. Shatin Heights is a nearby housing estate with lower average height, which fulfills the sixth standard of walled buildings.

\subsubsection{Shatin Heights}

Shatin Heights is a private housing estate, completed in October 1983. The average height of each block is far lower than Festival City, with eight floors only. It suffers from adverse effects of walled buildings: for instance, part of the view in some housing units has been blocked by Festival City.

\subsection{Variables Included in the Study}

The housing price is affected by the macroeconomic environment and different demand and supply-side factors [34], including wage level, labor force, and the rate of unemployment. Different variables are included in the model: its components comprise floor level and saleable area of walled buildings and affected private housing estates, natural light, view blockage, the temperature difference between urban areas and Waglan Island, the residential rental index, and housing price of affected private housing estates.

Transaction dates of housing units are recorded as an indicator to help select data. For instance, data entries of air temperature, Waglan Island air temperature, Residential Rental Index, wage level, labor force, and the rate of unemployment are recorded according to transaction dates. For example, if the housing unit is transferred or sold in December 2016, the air temperature of Waglan Island in December 2016 is recorded. In Table 1, variables and their characteristics are discussed; variables are explained in Table A1.

\section{Research Finding and Discussion}

The result is collected to analyze the relationship between walled buildings and housing price. Housing price acts as the dependent variable, while the remaining variables function as independent variables to show the relationship and effects on housing price. There are 11,365 observations, including transaction prices, macroeconomic data, and building features.

\subsection{Unit Root Test (Augmented Dickey-Fuller Test)}

The results are summarized in Tables $\mathrm{A} 2$ and $\mathrm{A} 3$, and the detailed results are shown in Tables A4-A11 for reference. If the box is marked ${ }^{*}{ }^{* *}$, or ${ }^{* * *}$, it means that the Augmented Dickey-Fuller test statistics are smaller than the one percent, five percent, and ten percent levels of critical value, respectively. If the box is marked \#, \#\#, or \#\#\#, this shows that the Augmented Dickey-Fuller test statistics are smaller than the one percent, five percent, and ten percent levels of critical value, respectively, when we carry out the tests for a unit root in first difference.

According to the tables, the Augmented Dickey-Fuller test statistics for most variables, which are marked with ${ }^{*}, *$, and ${ }^{* * *}$, are smaller than the one percent, five percent, and ten percent levels of critical value, respectively. Therefore, $\mathrm{H}_{0}$ can be rejected: this implies that unit roots do not exist. The above variables are stationary at one percent, five percent, and ten percent significance levels, respectively [22].

The natural light variable, which is marked with \#, is examined in tests for a unit root in the first difference to prove that it is stationary. This is because the results for this variable in tests for a unit root in level are nonstationary. As a result, tests for a unit root in first difference are conducted to turn the result from nonstationary to stationary. The Augmented Dickey-Fuller test statistics of variables 
are smaller than the one percent, five percent, and ten percent levels of critical value, respectively. Here, $\mathrm{H}_{0}$ can also be rejected, which implies that unit roots do not exist. Variables are stationary at one percent, five percent, and ten percent significance levels, respectively. If there is no unit root, the dataset is stationary. The results are shown in Table A2.

\subsection{Artificial Neural Network}

In this research, tests are conducted to observe the relationship between walled-building effects, macroeconomic factors, and housing price. Training rate and minimum and maximum number of layers are determined to obtain the most suitable models.

Tests are carried out for each pair, comprising walled buildings and the buildings which suffer from the effects of walled buildings. We firstly investigate whether walled buildings affect the housing price of buildings nearby, and therefore include variables such as floor levels and saleable area of walled buildings. To study the impact of walled buildings on the housing price of estates nearby, variables such as natural light, view blockage, and heat island effect are included. Individual housing units' prices are affected by housing features such as floor level and saleable area, macroeconomic situations (e.g., wage level, number of those in labor and unemployed), and housing market in the general residential rental index; thus, they are also included in the artificial intelligence model.

\subsection{Results}

\subsubsection{Grand Waterfront and Wyler Gardens}

In Grand Waterfront and Wyler Gardens, the testing rate is set at 15 percent, while the training rate is 70 percent. The minimum and maximum layers are four and 14, respectively. The model is chosen according to the degree of bias [28]; the weight is randomly selected by the model after learning the input data. The lower the bias, the better the result shown in the model.

First, high floor levels are the symbol of new private housing estates generally. More facilities are also provided, such as shopping malls and parks in the same district [33]. People who live nearby may also enjoy the public facilities, such as having more choices when buying daily necessities. Therefore, the housing price of Wyler Gardens slightly increased.

Second, there is a negative relationship between the saleable area of Grand Waterfront and the housing price of Wyler Gardens: this phenomenon may be caused by the design of housing units as compared by consumers. The better the design, the higher the housing price. As the design and decoration are more modern in new private housing estates generally, the housing price of Wyler Gardens is lower, as it was built in 1979.

Third, there are negative correlations among natural light, view blockage, and the housing price of Wyler Gardens. Negative effects are brought by blocked natural light [12], while the value of the housing units may slightly decrease. Therefore, the housing price of Wyler Gardens only reduces slightly.

Fourth, although there is a positive relationship between the heat island effect and housing price of Wyler Gardens, this seems unreasonable. Developers can have an arbitrage on earning a higher profit if the air ventilation paths have not been blocked [35] and the temperature is lower. Therefore, the housing price of Wyler Garden decreases if it suffers from the heat island effect. It is reasonable that there are positive relationships between floor level, saleable area, and housing prices of Wyler Gardens as per previous research [36]. According to the assumptions established in the previous chapter, a better view can be enjoyed if the floor level is higher.

Finally, it is observed that when there is an increase in the number of unemployed, the housing price decreases [37], because citizens have lower income levels. Therefore, when the wage level and labor force increases, the housing price should increase, meaning that the results of wage level and labor force seem unreasonable. There may be other factors to compensate for this and lead to results as such. 
In summary, the dominant factor affecting the housing price of Wyler Gardens is the floor level of Wyler Gardens.

\subsubsection{Harbour Green and Cosmopolitan Estate}

Regarding the second pair of housing estates, Harbour Green and Cosmopolitan Estate's testing rate is set at 15 percent [28], while the training rate is 70 percent. The minimum and maximum layers are again four and 14, respectively. The model is chosen according to the degree of bias [28]: the lower the bias, the better the result that will be presented. The results are shown in Table 1.

Table 1. Research results (authors' results).

\begin{tabular}{|c|c|c|c|c|c|c|c|}
\hline Variables & $\begin{array}{l}\text { Weight } \\
\text { Values }\end{array}$ & Variables & $\begin{array}{l}\text { Weight } \\
\text { Values }\end{array}$ & Variables & $\begin{array}{l}\text { Weight } \\
\text { Values }\end{array}$ & Variables & $\begin{array}{l}\text { Weight } \\
\text { Values }\end{array}$ \\
\hline $\begin{array}{l}\text { Floor level of Grand } \\
\text { Waterfront }\end{array}$ & 0.056042 & $\begin{array}{l}\text { Floor level of } \\
\text { Harbour Green }\end{array}$ & -0.11727 & $\begin{array}{l}\text { Floor level of Tolo } \\
\text { Place }\end{array}$ & 0.155377 & $\begin{array}{l}\text { Floor level of } \\
\text { Festival City }\end{array}$ & -0.82265 \\
\hline $\begin{array}{l}\text { Saleable area of } \\
\text { Grand Waterfront }\end{array}$ & -0.065848 & $\begin{array}{l}\text { Saleable area of } \\
\text { Harbour Green }\end{array}$ & 0.01031 & $\begin{array}{l}\text { Saleable area of } \\
\text { Tolo Place }\end{array}$ & -0.591885 & $\begin{array}{l}\text { Saleable area of } \\
\text { Festival City }\end{array}$ & 0.01264 \\
\hline Natural light & -0.104760 & Natural light & 0.03634 & Natural light & -0.043672 & Natural light & 0.62223 \\
\hline View block & -0.135182 & View block & 0.07782 & View block & -0.131823 & View block & 0.70658 \\
\hline Heat island effect & 0.098387 & Heat island effect & -0.24088 & Heat island effect & -0.033226 & Heat island effect & -0.16343 \\
\hline $\begin{array}{l}\text { Floor level of } \\
\text { Wyler Gardens }\end{array}$ & 0.423927 & $\begin{array}{l}\text { Floor level of } \\
\text { Cosmopolitan } \\
\text { Estate }\end{array}$ & 0.00159 & $\begin{array}{l}\text { Floor level of } \\
\text { Bayshore Towers }\end{array}$ & 0.093416 & $\begin{array}{l}\text { Floor level of } \\
\text { Shatin Heights }\end{array}$ & -0.25641 \\
\hline $\begin{array}{l}\text { Saleable area of Wyler } \\
\text { Gardens }\end{array}$ & 0.062405 & $\begin{array}{l}\text { Saleable area of } \\
\text { Cosmopolitan } \\
\text { Estate }\end{array}$ & 0.17547 & $\begin{array}{l}\text { Saleable area of } \\
\text { Bayshore Towers }\end{array}$ & 0.395586 & $\begin{array}{l}\text { Saleable area of } \\
\text { Shatin Heights }\end{array}$ & 0.85350 \\
\hline $\begin{array}{l}\text { Residential } \\
\text { rental index }\end{array}$ & -0.284368 & $\begin{array}{l}\text { Residential } \\
\text { rental index }\end{array}$ & 1.92177 & $\begin{array}{l}\text { Residential } \\
\text { rental index }\end{array}$ & 0.397907 & $\begin{array}{l}\text { Residential } \\
\text { rental index }\end{array}$ & 0.36067 \\
\hline Wage level & -0.004674 & Wage level & 0.68037 & Wage level & 0.054599 & Wage level & -0.14838 \\
\hline Labor force & -0.268774 & Labor force & 1.19692 & Labor force & -0.123071 & Labor force & -0.05541 \\
\hline Unemployed & -0.060732 & Unemployed & -0.94264 & Unemployed & 0.089363 & Unemployed & -0.27194 \\
\hline $\begin{array}{l}\text { Overall weight values } \\
\text { of housing price }\end{array}$ & 0.085546 & $\begin{array}{l}\text { Overall weight } \\
\text { values of housing } \\
\text { price }\end{array}$ & -0.76770 & $\begin{array}{l}\text { Overall weight } \\
\text { values of } \\
\text { housing price }\end{array}$ & 0.050132 & $\begin{array}{l}\text { Overall weight } \\
\text { values of } \\
\text { housing price }\end{array}$ & 0.08700 \\
\hline
\end{tabular}

The results show that there is a negative relationship between the floor level of Harbour Green and the housing price of Wyler Garden. The higher the floor level, the lower the housing price: this can be explained by the blocked natural light and view. This is because if most of the natural light and view have been blocked by walled buildings, more health problems will be generated [13]. The housing price is thus negatively affected. In addition, it is unreasonable to find that there are positive correlations between natural light, view blockage, and housing price of Cosmopolitan Estate.

Moreover, the higher the floor level, the more seriously the air ventilation path is hindered by walled buildings: thus, the heat island effect increases. Therefore, when there is a rise in temperature, the housing price plummets. Second, it is observed that the higher the floor level and saleable area of Cosmopolitan Estate, the higher the housing price which echoes the previous research [36]; this is because the living quality has been improved by a lower level of noise and fresher air. Third, it is reasonable to find positive relationships among residential rental index according to literature [38], wage level, labor force, and the housing price of Cosmopolitan Estate; the reason is that these factors drive the housing price in terms of macroeconomic factors. Moreover, when there is a high unemployment rate, people have lower income levels [37]. There is thus a downward trend in the demand for housing and the housing price declines.

On the whole, the dominant factor which affects the housing price of Cosmopolitan Estate is the residential rental index. 


\subsubsection{Bayshore Towers and Tolo Place}

The third case refers to Bayshore Towers and Tolo Place: the testing rate is set at 15 percent, while the training rate is 70 percent. The minimum and maximum layers are four and 14, respectively. The model is chosen to minimize bias [28]; the weight is randomly selected by the model after learning the input data. The lower the bias, the more accurate the result when running the model. Detailed results are displayed in Table 1.

It was found that the higher the floor level of Tolo Place, the more serious walled-building effects, and the housing price of Bayshore Towers thus declines. This can be proved by the negative correlations with blocked natural light, view blockage, and the heat island effect. In addition, it is unreasonable to find a positive correlation between the floor level of Tolo Place and the housing price of Bayshore Towers.

It is also reasonable to believe that the higher the floor level and the larger the saleable area of Bayshore Towers, the higher its housing price. A limited supply of housing units [1] could also be a factor. Finally, it is possible to observe that the higher the residential rental index [38] and wage level, the higher the housing price. Positive relationships are shown between the residential rental index and wage level: the residential rental index moves in the same direction as housing price when the housing market is booming. In addition, a higher income level is expected when the wage level increases; therefore, the housing price may move in the same direction.

The dominant factor which affects the housing price of Tolo Place is the saleable area of Tolo Place.

\subsubsection{Festival City and Shatin Heights}

The testing rate is set at 15 percent [28], while the training rate is 70 percent. The minimum and maximum layers are four and 14, respectively. The model is chosen according to the degree of bias [28]; the weight is randomly selected by the model after learning the input data. The lower the bias, the more accurate the result when running the model.

It is found that the higher the floor level of Festival City, the lower the housing price. Furthermore, the more serious the heat island effect, the lower the housing price of Shatin Heights; this is because buyers may prefer buying housing units with favorable weather conditions [4].

However, the results of natural light and view blockage are questionable: given that these are negative effects brought by walled buildings [13], housing price should decline instead of increase. In addition, Shatin Heights is a luxury apartment development, thus, it is not surprising that there is a positive correlation between saleable area and housing price of Shatin Heights. Finally, it is reasonable to observe that there is a positive relationship between residential rental index and housing price [38]: the high rental price drives the housing price.

On the whole, the dominant factor which affects the housing price of Shatin Heights is the saleable area of Shatin Heights. Detailed results of all models are shown in Table 1.

\section{Conclusions}

This research article has studied the characteristics of walled buildings and locations in Hong Kong; it provides the reader with a basic concept of walled buildings through collecting relevant literature. The definition of walled buildings is explained, and its characteristics are described with examples. The disadvantages of walled buildings are also provided to show the negative effects of this phenomenon in Hong Kong. Moreover, macroeconomic factors are included in order to examine further aspects. Information on two models is provided, introducing the background and ideas behind the models.

We adopted the augmented Dickey-Fuller model and an artificial neural network to study the impact of walled buildings on housing prices. Four pairs of housing estates are selected in this research, according to these criteria: (1) walled buildings exist in close proximity; and (2) affected housing estates are close to walled buildings. The selected building estates comprise Grand Waterfront and 
Wyler Gardens, Harbour Green and Cosmopolitan Estate, Bayshore Towers and Tolo Place, and finally, Festival City and Shatin Heights.

According to the results obtained using the artificial neural network, several factors affect housing prices:

- Walled buildings impose a negative impact on the housing price of private housing estates nearby. For example, Bayshore Towers suffers from all walled-building effects experiencing lower housing price, and the housing price of Wyler Gardens is negatively affected by the saleable area of Grand Waterfront.

- Heat island effect led to lower prices of Tolo Place and Harbour Green but not the Festival City and Grand Waterfront. Blocking of natural light lowers the prices of Grand Waterfront and Tolo Place. That indicates that some of the housing estates are adversely affected by walled building but not all. We speculate that there may be other factors which can compensate for the negative impacts or that echo with our previous research: when there is a shortage of housing supply, home buyers actually do not care about the housing quality [39] (previous research refers to the extra fitting provided by developers and now refers to the healthy building without the blockage of wind path and natural sunlight). That opens a new research agenda on the factors which may compensate for these impacts.

- Features of each housing estate can also be factors that affect its housing price. For instance, the housing price of Cosmopolitan Estate tends to be affected positively by its floor level and saleable area, with weight values of 0.00159 and 0.17547 , respectively.

- Macroeconomic factors can be reasons that lead to changes in housing price. The housing price of Cosmopolitan Estate is altered by macroeconomic factors, especially labor force, more strongly than by housing features and walled-building effects. Thus, the housing price is sensitive to the macroeconomic environment.

After all, although excess demand for housing is alleviated by walled buildings, the living environment is deteriorating. For instance, air paths which are blocked by walled buildings affect the air ventilation of the whole district. Moreover, air pollution problems and heat island effects have become unavoidable. Thus, the construction of walled buildings should be avoided so that environmental problems can be resolved.

The Hong Kong Special Administrative Region Government should review the current migration policy that allows approximately 150 migrants to enter Hong Kong from mainland China daily, and should reduce this quota to relieve the pressure on housing demand. As most air pollutants in urban areas are produced by heavy traffic, basal openings could be introduced beneath the towers of skyscrapers. Such measures would not only increase ventilation, but also reduce the air pollution problems associated with the heat island effect which has strong linkage with the heavy traffic on the street. Whilst the construction of towers of skyscrapers is unavoidable, providing vertical gardens and roof greening can alleviate the heat island effect brought by walled buildings. Furthermore, the planning department should not approve the construction of single-tower skyscrapers that block the wind flow between the dense clusters of buildings. Moreover, housing estates should be built with proper planning. For instance, the average height of housing estates built near the waterfront should be more carefully regulated by the government when developers apply for GFA concessions for installing green features and facilities. Moreover, the planning department and other related government bodies should ensure that any new building constructed does not partially block the important air paths, so as to alleviate the problem of heat island effect. The major problem that we observed, however, is that many of the new buildings planned to be built in Hong Kong are driven by government departments. One notorious example came from a rezoning application from the government which turns the playground in Tin Chiu Street in between clusters of buildings to one single block building that blocks the remaining wind corridor. That was, however, successfully approved by the Town Planning Board. 
In addition, the geographical location should be considered when designing and planning housing estates. For example, So UK Estate, designed by Eric Cumine, is a well-planned public housing estate. This is because environmental factors were considered within the design so that natural light and air ventilation are not blocked by walled buildings. Ultimately, scaling-up sustainability is a challenge due to the increasing numbers of stakeholders and parameters in the urban planning decision-making process [10]. Besides, percentage of porous land in relation to density and land use diversity substantially contributed to the UHI effect, careful land use planning are important [40].

Finally, as it is virtually impossible to include all the relevant variables in an econometric modelling, similar to any other research, omitted variable bias is unavoidable, the inclusion of a subset of control variables may lead to additional biases through measurement error, and the relevant control variables may not ameliorate, or may even increase the bias due to the existence of omitted variables [41].

Author Contributions: Rita Yi Man Li is responsible for the research design and writing. Ka Yi Cheng is responsible for paper writing and modelling. Muhammad Shoaib is responsible for paper writing, revising and editing.

Conflicts of Interest: The authors declare no conflict of interest.

\section{Appendix A}

Table A1. Variables and their characteristics (authors).

\begin{tabular}{|c|c|}
\hline Variables & Characteristics \\
\hline Saleable area of the housing unit & $\begin{array}{l}\text { According to the Residential Properties (First-Hand Sales) Ordinance, the floor area of the } \\
\text { residential property is counted as saleable area. The floor area of the balcony, a utility } \\
\text { platform, and a verandah are counted as saleable area. }\end{array}$ \\
\hline Floor level & $\begin{array}{l}\text { Residents living on higher floors enjoy more natural light. More views are blocked for } \\
\text { those living on the lower floor level. }\end{array}$ \\
\hline Housing price & The data of housing is collected from Center Data and Midland Realty. \\
\hline Natural light & $\begin{array}{l}\text { The higher the floor level, the more natural light can be enjoyed. Each of the residential } \\
\text { building towers is divided into four levels, comprising zero, } 25,50,75 \text {, and } 100 \text { percent. } \\
\text { Suppose we have a building of } 100 \text { stories high, } 0-25 \text { will be indicated by dummy } 1,26-50 \\
\text { will be } 2,51-75 \text { will be } 3 \text { and } 76-100 \text { is } 4 \text {. The percentage of natural light that people can } \\
\text { enjoy is divided into five levels: zero, } 25,50,75 \text {, and } 100 \text { percent. The higher the floor level, } \\
\text { the more natural light can be enjoyed. }\end{array}$ \\
\hline View block & $\begin{array}{l}\text { More fashionable walled buildings are designed and built so that the developers can make } \\
\text { huge profits from selling housing units. However, part of the view will then be blocked by } \\
\text { walled buildings. The housing price will be driven down due to the blocked view. } \\
\text { Therefore, it is considered as one of the variables. The percentage of view that has been } \\
\text { blocked by walled buildings is divided into five levels: zero, } 25,50,75 \text {, and } 100 \text { percent. } \\
\text { As a result, the blocked view is considered as one of the variables. }\end{array}$ \\
\hline Air temperature & $\begin{array}{l}\text { Monthly air temperature is recorded to observe the trends and changes in temperature in } \\
\text { districts. The data is collected from Hong Kong Observatory. }\end{array}$ \\
\hline Waglan Island air temperature & $\begin{array}{l}\text { Waglan Island is an island in Hong Kong without urbanization. The temperature in } \\
\text { Waglan Island is recorded and compared with other places in Hong Kong which have been } \\
\text { developed. Differences between the urban area and Waglan Island will be calculated to } \\
\text { show the effects of heat island effect brought by walled buildings. The data is collected } \\
\text { from Hong Kong Observatory. }\end{array}$ \\
\hline Residential rental index & $\begin{array}{l}\text { The residential rental index and the property price index tend to move in the same way [42]. } \\
\text { The rent and housing price in the same district are dependent. The changes in rent may } \\
\text { affect the housing price directly. As a result, the residential rental index is considered. }\end{array}$ \\
\hline Wage level & It is expected that higher wages shall lead to higher ability to pay for housing units. \\
\hline Labor force and unemployed & $\begin{array}{l}\text { Higher unemployment rates lower the potential for home purchase. The housing price } \\
\text { may decline. }\end{array}$ \\
\hline
\end{tabular}


Table A2. ADF result of Grand Waterfront, Wyler Gardens, Harbour Green and Cosmopolitan Estate (authors' results).

\begin{tabular}{ccccc}
\hline Data & Grand Waterfront & Wyler Gardens & Harbour Green & Cosmopolitan Estate \\
\hline Housing price & $*$ & $*$ & $*$ & $*$ \\
Natural light & $* *$ & $*$ & $*$ & $*$ \\
Air temperature (degree Celsius) & $*$ & $*$ & $*$ & $*$ \\
Waglan Island air temperature (degree Celsius) & $*$ & $*$ & $*$ & $*$ \\
Temperature difference (degree Celsius) & $*$ & $*$ & $*$ & $*$ \\
Residential rental index & $*$ & $*$ & $*$ \\
Wage level & $*$ & $*$ & $*$ \\
Labor force (in thousand) & $*$ & & $*$ \\
\hline
\end{tabular}

Table A3. ADF result of Bayshore Towers, Tolo Place, Festival City, and Shatin Heights (authors' results).

\begin{tabular}{ccccc}
\hline Data & Bayshore Towers & Tolo Place & Festival City & Shatin Heights \\
\hline Housing price & $*$ & $*$ & $*$ & $*$ \\
Natural light & $*$ & $*$ & $*$ & $*$ \\
Air temperature (degree Celsius) & $*$ & $*$ & $*$ & $*$ \\
Waglan Island air temperature (degree Celsius) & $*$ & $*$ & $*$ & $*$ \\
Temperature difference (degree Celsius) & $*$ & $*$ & $*$ & $*$ \\
Residential rental index & $*$ & $*$ & $*$ & $*$ \\
Wage level & $*$ & $*$ & $*$ \\
Unemployed (in thousand) & $*$ & & $*$ \\
\hline
\end{tabular}

Table A4. ADF result of Grand Waterfront (authors' results).

\begin{tabular}{|c|c|c|c|c|}
\hline Data & $\begin{array}{l}\text { ADF Test } \\
\text { Statistic }\end{array}$ & $\begin{array}{c}1 \% \text { Level } \\
\text { Critical Value }\end{array}$ & $\begin{array}{c}5 \% \text { Level } \\
\text { Critical Value }\end{array}$ & $\begin{array}{l}10 \% \text { Level } \\
\text { Critical Value }\end{array}$ \\
\hline Housing price & -7.489 & $-3.433 *$ & -2.862 & -2.567 \\
\hline Natural light & -2.840 & -3.433 & -2.862 & $-2.567 *$ \\
\hline Air temperature (degree Celsius) & -43.805 & $-3.433 *$ & -2.862 & -2.567 \\
\hline Waglan Island air temperature (degree Celsius) & -43.720 & $-3.433 *$ & -2.862 & -2.567 \\
\hline Temperature difference (degree Celsius) & -41.622 & $-3.433 *$ & -2.862 & -2.567 \\
\hline Residential rental index & -40.347 & $-3.433 *$ & -2.862 & -2.567 \\
\hline Wage level & -41.734 & $-3.433 *$ & -2.862 & -2.567 \\
\hline Labor force (in thousand) & -40.032 & $-3.433 *$ & -2.862 & -2.567 \\
\hline Unemployed (in thousand) & -42.378 & $-3.433 *$ & -2.862 & -2.567 \\
\hline
\end{tabular}

Table A5. ADF result of Wyler Gardens (authors' results).

\begin{tabular}{|c|c|c|c|c|}
\hline Data & $\begin{array}{l}\text { ADF Test } \\
\text { Statistic }\end{array}$ & $\begin{array}{c}1 \% \text { Level } \\
\text { Critical Value }\end{array}$ & $\begin{array}{c}5 \% \text { Level } \\
\text { Critical Value }\end{array}$ & $\begin{array}{c}10 \% \text { Level } \\
\text { Critical Value }\end{array}$ \\
\hline Housing price & -36.276 & $-3.434 *$ & -2.863 & -2.567 \\
\hline Natural light & -12.118 & $-3.434 *$ & -2.863 & -2.567 \\
\hline Air temperature (degree Celsius) & -39.049 & $-3.434 *$ & -2.863 & -2.567 \\
\hline Waglan Island air temperature (degree Celsius) & -39.144 & $-3.434 *$ & -2.863 & -2.567 \\
\hline Temperature difference (degree Celsius) & -39.256 & $-3.434 *$ & -2.863 & -2.567 \\
\hline Residential rental index & -38.926 & $-3.434 *$ & -2.863 & -2.567 \\
\hline Wage level & -38.807 & $-3.434 *$ & -2.863 & -2.567 \\
\hline Labor force (in thousand) & -37.769 & $-3.434 *$ & -2.863 & -2.567 \\
\hline Unemployed (in thousand) & -37.288 & $-3.434 *$ & -2.863 & -2.567 \\
\hline
\end{tabular}


Table A6. ADF result of Harbour Green (authors' results).

\begin{tabular}{|c|c|c|c|c|}
\hline Data & $\begin{array}{c}\text { ADF Test } \\
\text { Statistic }\end{array}$ & $\begin{array}{c}1 \% \text { Level } \\
\text { Critical Value }\end{array}$ & $\begin{array}{c}5 \% \text { Level } \\
\text { Critical Value }\end{array}$ & $\begin{array}{c}10 \% \text { Level } \\
\text { Critical Value }\end{array}$ \\
\hline Housing price & -5.216 & $-3.434 *$ & -2.863 & -2.567 \\
\hline Natural light & -3.245 & -3.434 & $-2.863 *$ & -2.567 \\
\hline Air temperature (degree Celsius) & -39.594 & $-3.434 *$ & -2.863 & -2.567 \\
\hline Waglan Island air temperature (degree Celsius) & -39.629 & $-3.434 *$ & -2.863 & -2.567 \\
\hline Temperature difference (degree Celsius) & -35.988 & $-3.434 *$ & -2.863 & -2.567 \\
\hline Residential rental index & -36.721 & $-3.434 *$ & -2.863 & -2.567 \\
\hline Wage level & -36.896 & $-3.434 *$ & -2.863 & -2.567 \\
\hline Labor force (in thousand) & -37.336 & $-3.434 *$ & -2.863 & -2.567 \\
\hline Unemployed (in thousand) & -36.672 & $-3.434 *$ & -2.863 & -2.567 \\
\hline
\end{tabular}

Table A7. ADF result of Cosmopolitan Estate (authors' results).

\begin{tabular}{|c|c|c|c|c|}
\hline Data & $\begin{array}{l}\text { ADF Test } \\
\text { Statistic }\end{array}$ & $\begin{array}{c}1 \% \text { Level } \\
\text { Critical Value }\end{array}$ & $\begin{array}{c}5 \% \text { Level } \\
\text { Critical Value }\end{array}$ & $\begin{array}{c}10 \% \text { Level } \\
\text { Critical Value }\end{array}$ \\
\hline Housing price & -32.546 & $-3.436 *$ & -2.864 & -2.568 \\
\hline Natural light & -4.481 & $-3.436 *$ & -2.864 & -2.568 \\
\hline Air temperature (degree Celsius) & -31.839 & $-3.436^{*}$ & -2.864 & -2.568 \\
\hline Waglan Island air temperature (degree Celsius) & -31.870 & $-3.436 *$ & -2.864 & -2.568 \\
\hline Temperature difference (degree Celsius) & -31.440 & $-3.436 *$ & -2.864 & -2.568 \\
\hline Residential rental index & -31.116 & $-3.436 *$ & -2.864 & -2.568 \\
\hline Wage level & -30.622 & $-3.436^{*}$ & -2.864 & -2.568 \\
\hline Labor force (in thousand) & -30.828 & $-3.436^{*}$ & -2.864 & -2.568 \\
\hline Unemployed (in thousand) & -31.385 & $-3.436^{*}$ & -2.864 & -2.568 \\
\hline
\end{tabular}

Table A8. ADF result of Bayshore Towers (authors' results).

\begin{tabular}{|c|c|c|c|c|}
\hline Variable & $\begin{array}{c}\text { ADF Test } \\
\text { Statistic }\end{array}$ & $\begin{array}{c}1 \% \text { Level } \\
\text { Critical Value }\end{array}$ & $\begin{array}{c}5 \% \text { Level } \\
\text { Critical Value }\end{array}$ & $\begin{array}{c}10 \% \text { Level } \\
\text { Critical Value }\end{array}$ \\
\hline Housing price & -25.70 & $-3.438 *$ & -2.865 & -2.568 \\
\hline Natural light & -4.726 & $-3.439 *$ & -2.865 & -2.568 \\
\hline Air temperature (degree Celsius) & -28.161 & $-3.438 *$ & -2.865 & -2.568 \\
\hline Waglan Island air temperature (degree Celsius) & -28.166 & $-3.438 *$ & -2.865 & -2.568 \\
\hline Temperature difference (degree Celsius) & -28.550 & $-3.438 *$ & -2.865 & -2.568 \\
\hline Residential rental index & -26.863 & $-3.438 *$ & -2.865 & -2.568 \\
\hline Wage level & -26.411 & $-3.438 *$ & -2.865 & -2.568 \\
\hline Labor force (in thousand) & -26.307 & $-3.438 *$ & -2.865 & -2.568 \\
\hline Unemployed (in thousand) & -28.520 & $-3.438 *$ & -2.865 & -2.568 \\
\hline
\end{tabular}

Table A9. ADF result of Tolo Place (authors' results).

\begin{tabular}{|c|c|c|c|c|}
\hline Result Data & $\begin{array}{l}\text { ADF Test } \\
\text { Statistic }\end{array}$ & $\begin{array}{c}1 \% \text { Level } \\
\text { Critical Value }\end{array}$ & $\begin{array}{c}5 \% \text { Level } \\
\text { Critical Value }\end{array}$ & $\begin{array}{c}10 \% \text { Level } \\
\text { Critical Value }\end{array}$ \\
\hline Housing price & -3.806 & $-3.441 *$ & -2.866 & -2.569 \\
\hline Natural light & -3.531 & $-3.441 *$ & -2.866 & -2.569 \\
\hline Air temperature (degree Celsius) & -22.332 & $-3.441 *$ & -2.866 & -2.569 \\
\hline Waglan Island air temperature (degree Celsius) & -22.549 & $-3.441 *$ & -2.866 & -2.569 \\
\hline Temperature difference (degree Celsius) & -22.634 & $-3.441 *$ & -2.866 & -2.569 \\
\hline Residential rental index & -24.902 & $-3.441 *$ & -2.866 & -2.569 \\
\hline Wage level & -24.195 & $-3.441 *$ & -2.866 & -2.569 \\
\hline Labor force (in thousand) & -22.752 & $-3.441 *$ & -2.866 & -2.569 \\
\hline Unemployed (in thousand) & -24.538 & $-3.441 *$ & -2.866 & -2.569 \\
\hline
\end{tabular}


Table A10. ADF result of Festival City (authors' results).

\begin{tabular}{|c|c|c|c|c|}
\hline Variable & $\begin{array}{c}\text { ADF Test } \\
\text { Statistic }\end{array}$ & $\begin{array}{c}1 \% \text { Level } \\
\text { Critical Value }\end{array}$ & $\begin{array}{c}5 \% \text { Level } \\
\text { Critical Value }\end{array}$ & $\begin{array}{c}10 \% \text { Level } \\
\text { Critical Value }\end{array}$ \\
\hline Housing price & -6.390 & $-3.431 *$ & -2.862 & -2.567 \\
\hline Natural light & -14.534 & $-3.431 *$ & -2.862 & -2.567 \\
\hline Air temperature (degree Celsius) & -3.324 & -3.431 & $-2.862 *$ & -2.567 \\
\hline Waglan Island air temperature (degree Celsius) & -3.519 & $-3.431 *$ & -2.862 & -2.567 \\
\hline Temperature difference (degree Celsius) & -3.833 & $-3.431 *$ & -2.862 & -2.567 \\
\hline Residential rental index & -2.741 & -3.431 & -2.862 & $-2.567 *$ \\
\hline Wage level & -2.886 & -3.431 & $-2.862 *$ & -2.567 \\
\hline Labor force (in thousand) & -2.953 & -3.431 & $-2.862 *$ & -2.567 \\
\hline Unemployed (in thousand) & -4.643 & $-3.431 *$ & -2.862 & -2.567 \\
\hline
\end{tabular}

Table A11. ADF result of Shatin Heights (authors' results).

\begin{tabular}{ccccc}
\hline Data & ADF Test & $\begin{array}{c}\mathbf{1 \%} \text { Level } \\
\text { Critical Value }\end{array}$ & $\begin{array}{c}\mathbf{5 \%} \text { Level } \\
\text { Critical Value }\end{array}$ & $\begin{array}{c}\mathbf{1 0 \%} \text { Level } \\
\text { Critical Value }\end{array}$ \\
\hline Housing price & -4.992 & $-3.646^{*}$ & -2.954 & -2.615 \\
Natural light & -5.657 & $-3.653 \#$ & -2.957 & -2.617 \\
Air temperature (degree Celsius) & -3.962 & $-3.646^{*}$ & -2.954 & -2.615 \\
Waglan Island air temperature (degree Celsius) & -3.949 & $-3.646^{*}$ & -2.954 & -2.615 \\
Temperature difference (degree Celsius) & -4.740 & $-3.646^{*}$ & -2.954 & -2.615 \\
Residential rental index & -5.112 & $-3.653^{*}$ & -2.957 & -2.617 \\
Wage level & -5.175 & $-3.653^{*}$ & -2.957 & -2.617 \\
Labor force (in thousand) & -5.666 & $-3.646^{*}$ & -2.954 & -2.615 \\
Unemployed (in thousand) & -6.292 & $-3.646^{*}$ & -2.954 & -2.615 \\
\hline
\end{tabular}

\section{References}

1. Huang, J.; Shen, G.Q.; Zheng, H.W. Is insufficient land supply the root cause of housing shortage? Empirical evidence from Hong Kong. Habitat Int. 2015, 49, 538-546. [CrossRef]

2. Hong Kong Institute of Planners. Developments Creating the Wall Effect. Available online: http://www.hk ip.org.hk/HK/Content.asp?Bid=7\&Sid=42\&Id=72 (accessed on 16 February 2018).

3. Yim, S.H.L.; Fung, J.C.H.; Lau, A.K.H.; Kot, S.C. Air ventilation impacts of the "wall effect" resulting from the alignment of high-rise buildings. Atmos. Environ. 2009, 43, 4982-4994. [CrossRef]

4. Greensense. Walled-Buildings. Available online: http://greensense.org.hk/en (accessed on 1 March 2018).

5. Jin, H.; Cui, P.; Wong, N.; Ignatius, M. Assessing the Effects of Urban Morphology Parameters on Microclimate in Singapore to Control the Urban Heat Island Effect. Sustainability 2018, 10, 206. [CrossRef]

6. Wong, M.S.; Nichol, J.; Ng, E. A study of the "wall effect" caused by proliferation of high-rise buildings using GIS techniques. Landsc. Urban Plan. 2011, 102, 245-253. [CrossRef]

7. Shi, Y.; Katzschner, L.; Ng, E. Modelling the fine-scale spatiotemporal pattern of urban heat island effect using land use regression approach in a megacity. Sci. Total Environ. 2018, 618, 891-904. [CrossRef] [PubMed]

8. Wong, M.S.; Nichol, J.E. Spatial variability of frontal area index and its relationship with urban heat island intensity. Int. J. Remote Sens. 2013, 34, 885-896. [CrossRef]

9. Aflaki, A.; Mirnezhad, M.; Ghaffarianhoseini, A.; Ghaffarianhoseini, A.; Omrany, H.; Wang, Z.-H.; Akbari, H. Urban heat island mitigation strategies: A state-of-the-art review on Kuala Lumpur, Singapore and Hong Kong. Cities 2017, 62, 131-145. [CrossRef]

10. Lourenço, P.; Pinheiro, M.D.; Heitor, T. From indicators to strategies: Key Performance Strategies for sustainable energy use in Portuguese school buildings. Energy Build. 2014, 85, 212-224. [CrossRef]

11. Li, R.; Li, H. Have Housing Prices Gone with the Smelly Wind? Big Data Analysis on Landfill in Hong Kong. Sustainability 2018, 10, 341. [CrossRef]

12. Edwards, L.; Torcellini, P. Literature Review of the Effects of Natural Light on Building Occupants; National Renewable Energy Lab.: Golden, CO, USA, 2002.

13. Shishegar, N.; Boubekri, M. Natural light and productivity: Analyzing the impacts of daylighting on students' and workers' health and alertness. In Proceedings of the International Conference on "Health, Biological and Life Science" (HBLS-16), Istanbul, Turkey, 18-19 April 2016.

14. Mantler, A.; Logan, A.C. Natural environments and mental health. Adv. Integr. Med. 2015, 2, 5-12. [CrossRef] 
15. Meng, Q.; Zhang, L.; Sun, Z.; Meng, F.; Wang, L.; Sun, Y. Characterizing spatial and temporal trends of surface urban heat island effect in an urban main built-up area: A 12-year case study in Beijing, China. Remote Sens. Environ. 2018, 204, 826-837. [CrossRef]

16. Zhou, D.; Bonafoni, S.; Zhang, L.; Wang, R. Remote sensing of the urban heat island effect in a highly populated urban agglomeration area in East China. Sci. Total Environ. 2018, 628-629, 415-429. [CrossRef] [PubMed]

17. Founda, D.; Santamouris, M. Synergies between Urban Heat Island and Heat Waves in Athens (Greece), during an extremely hot summer (2012). Sci. Rep. 2017, 7, 10973. [CrossRef] [PubMed]

18. Li, R.Y.M. Generation X and Y's demand for homeownership in Hong Kong. Pac. Rim Prop. Res. J. 2015, 21, 15-36. [CrossRef]

19. Lok, C. Major Factors Affecting the Residential Market Price in Hong Kong. Master's Thesis, The University of Hong Kong, Hong Kong, 2002.

20. Hanushek, E.; Yilmaz, K. Schools and location: Tiebout, alonso, and governmental finance policy. J. Public Econ. Theory 2013, 15, 829-855. [CrossRef]

21. Hanushek, E.; Yilmaz, K. The complementarity of Tiebout and Alonso. J. Hous. Econ. 2007, 16, $243-261$. [CrossRef]

22. Mahadeva, L.; Robinson, P. Unit Root Testing to Help Model Building; Centre for Central Banking Studies, Bank of England: London, UK, 2004.

23. Philips, A.Q. Have Your Cake and Eat It Too? Cointegration and Dynamic Inference from Autoregressive Distributed Lag Models. Am. J. Political Sci. 2018, 62, 230-244. [CrossRef]

24. Zhang, G.; Zhang, Z.; Gao, X.; Yu, L.; Wang, S.; Wang, Y. Impact of Energy Conservation and Emissions Reduction Policy Means Coordination on Economic Growth: Quantitative Evidence from China. Sustainability 2017, 9, 686. [CrossRef]

25. Tanzifi, M.; Yaraki, M.T.; Kiadehi, A.D.; Hosseini, S.H.; Olazar, M.; Bharti, A.K.; Agarwal, S.; Gupta, V.K.; Kazemi, A. Adsorption of Amido Black 10B from aqueous solution using polyaniline $/ \mathrm{SiO}_{2}$ nanocomposite: Experimental investigation and artificial neural network modeling. J. Colloid Interface Sci. 2018, 510, $246-261$. [CrossRef] [PubMed]

26. Etim, A.; Betiku, E.; Ajala, S.; Olaniyi, P.; Ojumu, T. Potential of Ripe Plantain Fruit Peels as an Ecofriendly Catalyst for Biodiesel Synthesis: Optimization by Artificial Neural Network Integrated with Genetic Algorithm. Sustainability 2018, 10, 707. [CrossRef]

27. Albert, L.P.; Keenan, T.F.; Burns, S.P.; Huxman, T.E.; Monson, R.K. Climate controls over ecosystem metabolism: Insights from a fifteen-year inductive artificial neural network synthesis for a subalpine forest. Oecologia 2017, 184, 25-41. [CrossRef] [PubMed]

28. Kaastra, I.; Boyd, M. Designing a neural network for forecasting financial and economic time series. Neurocomputing 1996, 10, 215-236. [CrossRef]

29. Hramov, A.E.; Frolov, N.S.; Maksimenko, V.A.; Makarov, V.V.; Koronovskii, A.A.; Garcia-Prieto, J.; Antón-Toro, L.F.; Maestú, F.; Pisarchik, A.N. Artificial neural network detects human uncertainty. Chaos Interdiscip. J. Nonlinear Sci. 2018, 28, 033607. [CrossRef] [PubMed]

30. Carleo, G.; Troyer, M. Solving the quantum many-body problem with artificial neural networks. Science 2017, 355, 602-606. [CrossRef] [PubMed]

31. Chokshi, P.; Dashwood, R.; Hughes, D.J. Artificial Neural Network (ANN) based microstructural prediction model for 22MnB5 boron steel during tailored hot stamping. Comput. Struct. 2017, 190, 162-172. [CrossRef]

32. Lek, S.; Guégan, J.-F. Artificial neural networks as a tool in ecological modelling, an introduction. Ecol. Model. 1999, 120, 65-73. [CrossRef]

33. Greensense. Walled Buildings in Hong Kong. Available online: http://www.legco.gov.hk/yr06-07/chinese / panels / plw/papers/ plw0227cb1-983-3-c.pdf (accessed on 16 February 2018).

34. Li, R.Y.M.; Chau, K.W. Econometric Analyses of International Housing Markets; Routledge: London, UK; New York, NY, USA, 2016.

35. Tong, S. Walled Buildings in Hong Kong. Master's Thesis, The University of Hong Kong, Hong Kong, 2009.

36. Chau, K.W.; Wong, S.K.; Yiu, C.Y. The value of the provision of a balcony in apartments in Hong Kong. Prop. Manag. 2004, 22, 250-264. [CrossRef]

37. Zhu, Q. Regional unemployment and house price determination. 2010. Available online: http://mpra.ub.un i-muenchen.de/41785/ (accessed on 11 January 2018). 
38. Gallin, J. The long-run relationship between house prices and rents. Real Estate Econ. 2008, 36, 635-658. [CrossRef]

39. Li, R.Y.M. Econometric modelling of risk adverse behaviours of entrepreneurs in the provision of house fittings in China. Constr. Econ. Build. 2012, 12, 11. [CrossRef]

40. Kamruzzaman, M.; Deilami, K.; Yigitcanlar, T. Investigating the urban heat island effect of transit oriented development in Brisbane. J. Transp. Geogr. 2018, 66, 116-124. [CrossRef]

41. Clarke, K.A. The Phantom Menace: Omitted Variable Bias in Econometric Research. Confl. Manag. Peace Sci. 2005, 22, 341-352. [CrossRef]

42. Hong Kong Monetary Authority. What Drives Property Prices in Hong Kong. Available online: http:/ / www.hkma.gov.hk/media/eng/publication-and-research/quarterly-bulletin/qb200208/fa2.pdf (accessed on 1 March 2018).

(C) 2018 by the authors. Licensee MDPI, Basel, Switzerland. This article is an open access article distributed under the terms and conditions of the Creative Commons Attribution (CC BY) license (http://creativecommons.org/licenses/by/4.0/). 